\title{
RECREACIÓN GROTESCA Y NUEVOS ARABESCOS: LO GROTESCO EN EL TEATRO DE ANTONIA BUENO Y DE ANA VALLÉS
}

\author{
GROTESQUE RECREATION AND NEW ARABESQUES: \\ THE GROTESQUE IN ANTONIA BUENO \\ AND ANA VALLÉS' THEATRE
}

\author{
Agnès SURBEZY \\ Université de Toulouse-le Mirail (Francia) - LLA/Creatis \\ agnes.surbezy@univ-tlse2.fr
}

Resumen: De la dramaturgia de la recreación y de la re-creación de Antonia Bueno a la escenificación de la desubicación y la corporalidad de Ana Vallés, las propuestas de ambas creadoras se valen de lo grotesco para renovar la mirada del receptor sobre el mundo.

Abstract: From the Antonia Bueno's dramatic art of recreation and re-creation to the Ana Vallés' directions based on nonconformist and corporeal expression, the propositions of these two creators use the grotesque to renew the spectator's perception of the world.

Palabras clave: Dramaturgas. Grotesco. Puesta en escena. Escritura dramática. Antonio Bueno. Ana Vallés.

Key Words: Playwrights Women. Grotesque. Direction. Dramatic Writing. 
Definir lo grotesco no deja de ser problemático: basta con pensar en las definiciones divergentes de críticos como Mikhaël Bakhtine y Wolfgang Kayser $^{1}$, tan importantes en relación con el tema. Esta dificultad la señala PhilippeWellnitz en su artículo «Le grotesque littéraire-simple style ou genre à part entière?» (Wellnitz, 2004), recalcando la ambigüedad y el carácter movedizo de esta noción. La tensión subyacente en el concepto - tensión característica de lo grotesco- - la notamos claramente en la observación de Raquel García Pascual:

Todas las poéticas del grotesco del siglo XX estudian en su campo semántico el capricho, la extravagancia y la extrañeza, pero también lo sórdido y lo revulsivo, lo grosero, estrafalario, ridículo y desproporcionado. Grotesco es, de un lado, lo deformado y, de otro, lo irrisorio (García Pascual, 2006: 23).

Tal vez por su esencia profundamente conflictiva, el teatro parece ser un terreno fértil a la hora de interesarse por lo grotesco. Es de notar, por ejemplo, la evidente predominancia de las reflexiones acerca de obras dramáticas en el volumen Le grotesque. Théorie, généalogie, figures, volumen presentado como un estudio de lo grotesco desde la perspectiva de los estudios literarios y filosóficos (Ost et alii, 2004).

En este trabajo, intentaremos analizar la dimensión grotesca de una selección de textos y espectáculos de Antonia Bueno y Ana Vallés, mujeres de teatro, dedicadas tanto la una como la otra a la escritura y puesta en escena de sus espectáculos, directoras de compañías ${ }^{2}$, actrices... Cabe señalar, sin embargo, una diferencia: los textos de Antonia Bueno suelen estar destinados a la escena, pero también a la edición, mientras que el teatro de Ana Vallés es un teatro esencialmente escénico, siendo el texto tan sólo un guión, un soporte para un trabajo colectivo, en el que la dimensión escénica, el trabajo corporal, la búsqueda de una renovación en profundidad del teatro contemporáneo son fundamentales. Por eso, basaremos nuestro trabajo en soportes distintos: textos dramáticos en el caso de Antonia Bueno y vídeos en el de Ana Vallés. Será interesante pues, además de indagar en la presencia de lo grotesco en algunas de sus producciones, preguntarnos si la diferencia de estatuto concedido al texto conlleva una diferencia en cuanto a las manifesta-

\footnotetext{
${ }^{1}$ La visión del grotesco, más bien negativa, de Kayser lo relaciona con el mundo alienado, preso de las fuerzas demoniacas, mientras que la de Bakhtine radica en la idea de que el grotesco no es sino la expresión literaria de la tradición de la risa popular, relacionándolo con lo carnavalesco.

${ }^{2}$ Ana Vallés dirigía hasta este año la compañía gallega Matarile Teatro y Antonia Bueno dirigió de 1979 a 1998 la compañía Guirigai y en el 2000 fundó su propio grupo, la Compañía Antonia Bueno.
} 
ciones de lo grotesco. Para llevar a cabo esta reflexión, hemos elegido centrarnos en tres textos breves de Antonia Bueno, siendo éstos, según la propia autora, los más grotescos (Opereta de Caperucita y el lobo feroz, Sobaco y Axila, Todo por un duro) y en dos espectáculos de Ana Vallés, Truenos y misterios y Animales artificiales ${ }^{3}$.

\section{1. ¿ESCRITURA DE LO GROTESCO O ESCRITURA GROTESCA?}

Aunque no se conforma con la escritura teatral, sino que la articula con la escenificación, los textos de Antonia Bueno, como mencionábamos, son textos acabados, potencialmente destinados a la publicación. Nos permitirán, pues, estudiar una manifestación más bien textual de lo grotesco (lo que no quita la posibilidad de una escenificación susceptible de añadir elementos grotescos más visuales o físicos, fuera de los presentes en la dramaturgia textual).

Es de notar que, entre la producción calificada por Antonia Bueno como grotesca, predomina la forma breve. En su ensayo sobre «lo grotesco en las obras breves de los autores de tendencia neorrealista y neovanguardista», Raquel García Pascual señala efectivamente que «las piezas breves grotescas son formas contraculturales de utilización recurrente por su fuerza subversiva» (García Pascual, 2006: 23). Veremos cómo, subvirtiendo esquemas y tópicos, el teatro breve grotesco de Antonia Bueno cuestiona clichés y tópicos y renueva tanto las temáticas como la recepción.

\subsection{La Vía Dolorosa del pecador: Todo por un duro}

Todo por un duro (2004) es un monólogo dividido en ocho secuencias de un hombre llamado Matías Orozco. Va a vivir una como Vía Dolorosa

\footnotetext{
${ }^{3}$ Se podrían analizar más obras tanto de Antonia Bueno (como de Ana Vallés) desde la perspectiva de lo grotesco, pero nos pareció más pertinente limitar el corpus para dedicar más atención a las obras elegidas, que nos parecieron particularmente significativas, incluso entre producciones consideradas por la propia dramaturga como grotescas. Efectivamente, Antonia Bueno nos informó de unos trece textos suyos que considera grotescos: 7 minutos nada menos, Aulidi, Bits, El negro que tenía la pluma blanca, El otro, En capilla, La madrastra de Cenicienta, Ópera de los residuos, Opereta de Caperucita y el lobo feroz, Quien fue a Sevilla, Sí... pero no se calienta, Sobaco y axila, Todo por un duro. Aprovecho la oportunidad para agradecer tanto a Antonia Bueno como a Ana Vallés su disponibilidad y el material textual y audiovisual proporcionado. Una reflexión sobre su concepción del teatro breve puede verse en Antonia Bueno (2011).
} 
diabólica, recorriendo sucesivamente los siete pecados capitales. Acaba alejándose de la tentación no por sentido moral, sino por... ceder a la pereza.

\subsubsection{La perversión de los valores: ¿el burlador burlado?}

Es interesante notar que encontramos en la didascalia inicial, así como en la didascalia de la fuente locutoria, informaciones a las que el espectador no tendrá un acceso directo, pero que son ya indicios de la perversión de los valores que prevalece en este texto contribuyendo a su dimensión grotesca. Ya de por sí, en efecto, hay una distorsión entre la apariencia de víctima del personaje que «camina la cabeza gacha, arrastra con desgana la vieja bolsa de plástico que ya no volverá a oler a bocadillo de chorizo» y la realidad del personaje: como reza, no sin humor, la acotación, «le han acusado de desfalco. Y lo malo es que tienen razón», y que va a dar señales de su debilidad cayendo, de pensamiento como mínimo, en los siete pecados capitales. La distorsión se presenta también a nivel de la onomástica, oponiendo el nombre Matías, que remite al apóstol, con su condición, explícita ya desde el título de la primera secuencia, de «pecador». El nombre crea, además, una «hiperbolización» de esta dimensión por la tensión que instaura.

Este fenómeno de «hiperbolización», que se inscribe entre los rasgos propios de lo grotesco, se hace directamente perceptible para el espectador por el espacio, exageradamente desierto y de mala muerte, y por la desproporción entre la reacción del protagonista y el estímulo que la genera (o sea «sólo un duro»): «¡Hostias!... ¡ Un duro! (Lo mira con deleite, confirmando su hallazgo.) Un duro nuevecito... redondito... resplandeciente. ¡Un duro de verdad! (Le lanza un beso.)» (2. ${ }^{a}$ secuencia). Se prolonga con la verdadera verborrea que va a permitir el paso por los pecados capitales, uno tras otro, desde el más evidente, la avaricia, hasta la pereza. El uso de la hipérbole contamina finalmente el conjunto del discurso, caracterizado por la exageración (tanto más cuanto que se trata sólo de un duro): «¿Por qué tener que conformarme con una... cuando puedo tener una docena?» (3. ${ }^{a}$ secuencia), «iPienso comer hasta hartarme!... ¡Hasta perder el sentido!... ¡iHasta reventar!!» (7. ${ }^{\text {a }}$ secuencia), «Un duro... ¡Un duro es una mierda! ¡Eso es lo que es!... ¡¡Una auténtica mierda!!» (8. ${ }^{a}$ secuencia). Otro vector de «hiperbolización» es la puntuación, sobre la base de que hay innumerables puntos exclamativos que alternan con interrogaciones principalmente retóricas. Esta multiplicación de elementos hiperbólicos resta verosimilitud a la situación, aunque podemos suscribir aquí las palabras de Raquel García Pascual acerca de lo grotesco en los textos breves: 
Si [...] se exageran los rasgos que caracterizan a los personajes, tanto como su lenguaje y el espacio en el que se mueven, que queda afantochado, esta medida de distorsión insólita y excéntrica hasta lo irreal quiere acusar, con mordacidad, una problemática social real (García Pascual, 2006: 23).

Pero, como bien se sabe, el Diablo está en los detalles y el burlador acaba burlado: después de un recorrido de cinco páginas tras el famoso duro, inspirado por la pereza, el protagonista abandona el objeto de la tentación y sigue su camino con las manos vacías: «(Matías desaparece tragado por la noche y el destino. El duro queda solo, en mitad del paisaje. Aguardando, tal vez, la llegada de un nuevo pecador.)». La didascalia final recalca la inutilidad de cuanto hizo, dijo y pensó Matías, que acaba siendo víctima de sí mismo lo miremos como lo miremos: no posee el duro y cedió a los siete pecados sin siquiera poder gozar de la transgresión. Incluso el aparente triunfo de la pereza viene manchado por el trabajo que le costó. En otras palabras, se crea una desproporción, una distorsión entre los (des)propósitos del protagonista y la acción, entre la verborrea que presenciamos y el resultado final. Dicha distorsión lo subvierte todo, participando del proceso de reescritura de los tópicos religiosos y alimentando lo grotesco de este texto breve.

\subsubsection{Reescritura y carnavalización del Via crucis}

De hecho, asistimos al recorrido del protagonista por etapas determinadas - los siete pecados capitales - claramente relacionadas con la religión cristiana. Pero lo notable es que este recorrido transita no por las catorce estaciones del via crucis, sino por su contrario: no se trata de una redención sino de una caída. No podemos sino pensar en esta subversión del modelo viendo el recorrido (mental) de Matías Orozco, que se caracteriza por una verborrea sembrada de palabrotas y vulgaridades: «iSeré gilipollas!» (2. ${ }^{a}$ secuencia), «iLa hostia!... [...] La Sandra... ¡Un putón verbenero!... [...] ;Y luego... tirármela sin contemplaciones... y sin gasto!» (3. ${ }^{a}$ secuencia), «iPues, os vais a reír de vuestro puñetero padre!... ¡Cabronazos! ¡Iros a cachondear de la madre que os parió!» (5. a secuencia). El lenguaje coloquial y vulgar es otra característica de lo grotesco, tanto más cuanto que se inscribe aquí en un proceso de carnavalización; carnavalización por la inversión de los valores, por la liberación y escenificación de contravalores abiertamente expuestos y reivindicados. Carnavalización también por subrayar, mediante una inversión humorística de los valores, el carácter dual del mundo. Cabe mencionar, 
para acabar con la evocación de este texto, el estatuto particular del duro, de esta moneda, de poco valor, que se convierte no sólo en una tentación irreprimible, sino también en una síntesis de todas las tentaciones, que quedan ridiculizadas por la desproporción que introduce entre el carácter insignificante del objeto y la dimensión capital de los pecados aludidos.

Más aún, este pequeño objeto se transforma en protagonista, en interlocutor de Matías Orozco: «Bueno, basta de charla y vámonos para casa, que aquí nos estamos helando. ¡Te va a gustar!... No es un palacio, pero está razonablemente limpia y confortable. En confianza: A mí eso de la limpieza me parece una pérdida de tiempo» (8. ${ }^{a}$ secuencia). Este considerar un objeto como si fuera un ser, como si fuera un interlocutor de pleno derecho - base de la antropomorfización-, así como el monologar sin cesar, pasando por estados tan claramente identificados y vehementes, pueden sugerir al receptor una forma de locura. Y eso otra vez relaciona este texto con lo grotesco: «la folie échappe aux normes et aux règles de la raison, donne une visión deformante et déformée de la réalité, ce qui en fait une des figures majeures du grotesque» (Surbezy, 2002: 63). Esta inscripción en la vena grotesca no sólo participa de la diversión del receptor; permite también cuestionar los modelos establecidos y los valores aceptados comúnmente y recordar la ambivalencia fundamental del mundo (tanto más cuanto que, como lo dijimos, si el protagonista acaba alejándose del objeto de la tentación, lo hace por mera pereza y no por motivos morales).

\subsection{Cuerpo humano, cuerpo animal: Opereta de Caperucita y el lobo feroz}

Opereta de Caperucita y el lobo feroz (1993), como lo indica el título, es una reescritura de Caperucita roja en la que «una caperucita actual [...] contempla como espectadora otra posible historia de Caperucita, en este caso burlesca y barroca» (didascalia de apertura). En esta versión moderna el lobo se convierte en el amante de la madre, también deseado abiertamente y provocado sexualmente por la hija.

\subsubsection{Un cuento no tan infantil}

La voluntad de reapropiación del modelo, distanciándose de éste, se hace patente en la presencia escénica de las dos Caperucitas, una de las cua- 
les (una «Caperucita actual») se convierte en espectadora, siendo así un doble del receptor. De hecho, asistimos a una mise en abyme que pone en cuestión el modelo desde el interior, a la vez que cuestiona el estatuto del espectador: «La acción de esta opereta se desarrolla en un teatrito rococó, al que llega nuestra protagonista, y donde contempla como espectadora otra posible historia de Caperucita». Este distanciamiento facilita la (re)conversión del cuento (escrito para adultos, pero considerado en la mente colectiva como lectura juvenil) en una obra literaria y teatral para adultos. Es más, el juego con las identidades, la construcción de cajas chinas se acentúa con la presencia escénica del mismo Perrault haciendo de lobo y convirtiéndose en el héroe, el galán: «Y por último verán/ al auténtico galán./ El héroe, no el malvado,/ el por todos despreciado./ Seré yo mismo, Perrault./ Yo seré... el lobo feroz». O sea que en este texto, como en el estudiado antes, presenciamos una inversión de los valores, una subversión de los tópicos (aquí literarios), con una tonalidad humorística reforzada en la réplica de Perrault por un juego con el horizonte de expectativas del receptor reforzado por la puntuación: los puntos suspensivos provocan una dilatación del tiempo que acentúa el efecto de sorpresa en cuanto al papel desempeñado por el mismo Perrault.

La subversión del modelo pasa también por una fuerte erotización del texto, siendo el deseo físico y el acto sexual los principales motores y resortes de la acción dramática. Si bien existen lecturas psicoanalíticas (Bruno Bettelheim, Luce Guillerm) del cuento que lo interpretan como la iniciación de la niña a la edad adulta o la representación de la desfloración, en ningún caso la dimensión sexual es tan explícita como en esta obra teatral en la que, además, la acción escénica viene a duplicar la explicitación verbal:

(La madre canturrea llamando al lobo, que se asoma y la mete con él. [...]) (Sale el lobo agotado.)

\section{LOBO-Esa dama es indomable,} esa hembra es insaciable, me hace perder la razón.

Si no repongo mis fuerzas, moriré del corazón.

Unos minutos después es Caperucita quien «le abanica, enseñando las bragas». Y esta omnipresencia de la sexualidad, su manifestación o sugestión escénica excesiva remite al uso de lo bajo corporal propio de lo grotesco, otorgándole importancia a la materialidad corpórea, los orificios, las apertu- 
ras que permiten una continuidad entre lo interior y lo exterior subvirtiendo el estereotipo tradicional.

\subsubsection{Reescritura grotesca y subversión genérica}

La reescritura se caracteriza no sólo por un desdoblamiento de Caperucita y una identificación de Perrault con el lobo, por la mise en abyme del cuento y de la representación teatral o por una presencia exagerada del componente sexual, sino que adquiere una dimensión paródica, forma derivada, según Bakhtine, de la máscara característica de lo grotesco:«ll faut simplement noter que des phénomène comme la parodie, la caricature, les simagrées, les singeries ne sont au fond que des dérivés du masque. C'est dans le masque que se révèle avec éclat l'essence profonde du grotesque» (Bakhtine, 1998: 49). Cabe señalar, de paso, que si buscamos las figuras explícitas o derivadas de la máscara en Opereta de Caperucita y el lobo feroz, vamos a comprobar que son numerosas y variadas. La más evidente es la máscara de lobo de Perrault: «Yo seré... el lobo feroz./ (Se pone el hocico de lobo.)», máscara que se concentra en la cara y más aún en la nariz, parte del cuerpo particularmente propicia para el desarrollo de lo grotesco: Bakhtine afirma que «les formes de la tête, des oreilles, et aussi du nez, ne prennent de caractère grotesque que lorsqu'elles se transforment en formes d'animaux ou de choses» (Bakhtine, 1998: 315); pero señala también que la nariz por su prominencia se acerca al sexo masculino, adquiriendo un valor particular en la expresión de lo grotesco. Además, Perrault se pone la máscara a la vista del espectador, asumiendo, en un proceso metateatral, el cambio de papel y favoreciendo la ambivalencia del personaje, autor/personaje, bueno/malo... Máscara también es la de madre atenta que adopta la Madre de Caperucita, cuando lo que pretende es quitarse de encima a la hija para quedarse con el lobo-amante:

MADRE- Una estrategia tengo que urdir.

Caperucita debe partir.

(Sale Caperucita.)

CAPERUCITA- Hola, mamita. [...]

MADRE-Es una niña tan relamida...

(A Caperucita.)

Caperucita, querida hijita,

está en cama tu abuelita 
con un catarro cruel.

Para su tos aliviarle,

esta cesta has de llevarle

con una torta de miel.

Así como la madre de la opereta parodia abiertamente a la madre del cuento, escondiéndose detrás de una máscara, la Caperucita de la opereta se aleja del modelo al que pretendía en un principio adecuarse, el de la niña cariñosa, temerosa del lobo:

LOBO- ¡Qué gran desdicha estar agotado

y rechazar tan rico bocado!

CAPERUCITA-Mira las blondas de mis enaguas.

Bébete el agua de mi jardín.

(Le acorrala.)

Acaba incluso convirtiéndose ella también en predadora sexual, acosando al lobo.

El juego de máscaras no se limita al trabajo actoral y la acción escénica: pasa también por la ambivalencia de la escritura y la subversión de los géneros. El título mismo de la obra atestigua el paso de un género, el cuento, a otro, la opereta, siendo ya ésta una forma cómica e híbrida, mezcla de textos cantados y declamados. Pero esta clasificación genérica viene cuestionada por la primera réplica de Perrault, que nos propone «ver el cuento de Caperucita», en un «teatrito rococó», sugiriendo la presencia del cuento en una representación teatral inserta en una opereta. Esta escritura que juega con los límites de los géneros y el efecto de cajas chinas tiene otra característica interesante: la polifonía particularmente visible al final, en la que la yuxtaposición de voces y lenguas confiere al texto un dialogismo que genera una impresión de caos a la vez que recuerda y cuestiona la universalidad del modelo:

LOBO- ¿Has ido a ver a tu abuela?

(Dirigiéndose a la Caperucita espectadora.)

¿Has ido a ver a tu abuela?

(Sale la madre.)

MADRE-¿Has ido a ver a tu abuela?

CAPERUCITA-¿HAas ido a ver a tu abuela?

TODOS-Est-ce que tu es allée voir ta grand-mère? 
Did you go to visit your grandmother?...

(Las voces se acumulan en diversos idiomas. Caperucita huye desconcertada.)

La huida final de la Caperucita espectadora marca el final de la obra, como si prefigurara la salida de los espectadores, pero cuestiona también el cuento, su validez hoy en día y su adecuación con una sociedad actual marcada por el consumo desenfrenado, la exhibición del cuerpo y de la sexualidad.

\subsection{Cuando el cuerpo habla al cuerpo: Sobaco y Axila}

Sobaco y Axila (2005) es el encuentro de dos personajes, Axila y Sobaco, en una discoteca, un encuentro que, de repente, aparece como una evidencia.

\subsubsection{Axila y Sobaco: ¿encuentro cercano del tercer tipo o evidencia fisiológica?}

Tan sólo leyendo el título, el receptor puede sorprenderse: remite a partes del cuerpo (que resultan ser los mismos personajes) y las asocia creando una redundancia puesto que designan la misma parte del cuerpo. Profundizando un poco, el lector/espectador se da cuenta de que esta similitud esconde una diferencia que va a ser esencial: asocia un término masculino y otro femenino. Esta percepción se confirma con la didascalia inicial:

(Música de discoteca. Un hombre y una mujer se observan mientras se contonean levemente al ritmo de la música. Él es un hombre de aspecto rudo y «viril». Ella, una mujer elegante y «femenina».)

SOBACO- ¿Bailas?

AXILA-Bueno.

De ahí derivamos los siguientes interrogantes: ¿son los personajes personificaciones de las partes del cuerpo? ¿Son nombres extraños pero referidos a seres humanos? ¿Qué significa la sinonimia de los nombres? Estas dudas vienen generadas por el juego con las palabras, el semantismo, el género, que es una de las características de lo grotesco:

Ce sont avant tout des jeux de mots, des expressions courantes (proverbes, dictons), des associations courantes de mots pris hors de l'ornière traditionnelle du lien logique. Une sorte de récréation des mots et des choses 
lâchés en liberté, délivrés de l'étreinte du sens, de la logique, de la hiérarchie verbale (Bakhtine, 1998: 420).

El desplazamiento del significado de las palabras y el juego con éstas es subrayado por las reacciones que suscitan en el interlocutor:

SOBACO-Me llamo Sobaco.

AXILA-Yo, Axila.

SOBACO- ¿Axila?... ¿Qué nombre tan raro!

AXILA-Pues anda que el tuyo: So-ba-co...

SOBACO- ¿Eres extranjera? Tu nombre me suena a árabe... o algo así.

AXILA-Pues el tuyo, lo menos es polaco.

Este juego lo duplica el intercambio acerca de los apellidos de los personajes. Un intercambio que se presta al mismo tipo de manipulación que los nombres, desde la «resemantización» hasta la deformación, pasando por la necesidad de deletrear un apellido extraño:

SOBACO-Sobaco. Sobaco Zapata. Para servir a Dios y a usted.

AXILA-Zapata... (Se retira de él, haciendo referencia a su mal olor.) No me extraña. Hueles a pies.[...]

AXILA- (Orgullosa.) Axila Gómez Déodorant.

SOBACO- (Desternillándose de risa.) ¿De qué?

AXILA - (Mirándole despreciativamente.) De nada: Dé-o-do-rant. Es un apellido francés. Mi madre era francesa... según me han dicho. Yo nací allí.

Estos juegos crean unas asociaciones humorísticas: la asociación entre contrarios (mal olor y desodorante), a la vez que la evidencia de un encuentro entre dos entidades similares.

\subsubsection{El baile de lo bajo corporal}

Estos juegos coinciden con elementos que no dejan de ser divertidos y que logran vincular la obra a una dimensión fisiológica que parece confirmar la hipótesis de la personificación de partes del cuerpo. Axila y Sobaco no pueden disociarse:

(Axila avanza ufana hasta el proscenio. Pero al llegar allí se frena. Algo la detiene, como una barrera invisible que no puede atravesar.) 
SOBACO- (Triunfal.) ¡Ay, Axila, Axilita!... Te lo dije y no me creíste. Nuestros destinos están indisolublemente unidos.

Esta dimensión fisiológica facilita alusiones múltiples a lo bajo corporal, esenciales en la constitución de la escritura grotesca. No sólo se trata de referencias a la materialidad del cuerpo, mediante una parte generalmente ignorada por el arte o por lo menos poco valorizada. La referencia al (mal) olor de Sobaco es un tópico humorístico, una referencia estereotipada a lo bajo corporal, del mismo modo que la alusión al (mal) olor de los pies. El juego con los clichés es fuente de humorismo y complicidad con el receptor. Permite provocar una risa popular y primitiva: «le rire populaire qui organise toutes les formes du réalisme grotesque a été lié de tout temps au bas matériel et corporel. Le rire rabaisse et matérialise» (Bakhtine, 1998: 29). Esta predominancia de lo bajo corporal, de la materialidad fisiológica, viene reforzada por el contexto del encuentro entre Sobaco y Axila: el baile, la seducción física, el «tórrido abrazo».

Esta materialidad fisiológica se hace patente también con las alusiones a sensaciones primitivas como el tener frío o calor. Es el caso en el que, por fin, descubrimos la explicación de este encuentro tan sorprendente como evidente:

SOBACO-Pues... ital vez, porque hoy ha empezado el verano! (Automáticamente.) Y nos han dejado libres.

AXILA- ¿Cómo?

SOBACO-(Confuso.) No sé por qué he dicho eso.

AXILA- ¡Claro! En invierno hacía frío...

SOBACO-Íbamos tapados. Yo no podía verte.

AXILA- Yo no podía... olerte.

(Se miran atónitos.)

SOBACO- ¿Tú siempre has estado aquí?

AXILA-Siempre.

SOBACO-A la derecha, claro... Yo también he estado aquí siempre.

AXILA- A la izquierda, por supuesto.

Pero este encuentro fisiológico y grotesco, no deja de plantear cuestiones metafísicas, de interrogar el ser y el estar en el mundo:

SOBACO-O sea, que vosotras siempre habéis estado a la derecha.

AXILA-Siempre. Y vosotros siempre a la izquierda... ¿Y qué habrá... en medio? 
(Se crea un silencio embarazoso. Ambos se miran confusos.)

SOBACO-Bueno... ;Algo tendrá que haber! [...]

AXILA-A lo mejor... mañana... encontramos la salida...

SOBACO-A lo mejor fuera hay algo...

AXILA-Algo... Aunque sea feo... o triste... Aunque sea una nueva interrogación...

El encuentro grotesco, pues, de Sobaco y Axila permite a partir del humor y del desplazamiento, dar una visión distinta, renovando cuestionamientos tenidos por inamovibles.

\section{GROTESCO ESCÉNICO, DE LO VERBAL A LO CORPORAL}

\subsection{Entre truenos y misterios, ¿la grotesca tragedia del mundo?}

Resumir las creaciones de Ana Vallés es un reto, casi una imposibilidad, por su dimensión fundamentalmente escénica y visual, y por huir ésta del argumento. Nos apoyaremos, pues, en las palabras de la propia Ana Vallés, según su propia descripción de Truenos y misterios (2007) en el sitio web de la compañía Matarile Teatro:

Un científico, un maestrillo de escuela y actor, un bailarín y licorero, el profesor, y yo. [...] Eliminado el decorado y extraídos de su entorno - una fábrica de coches, un ballet nacional, una escuela, un taller de marionetas o un laboratorio de universidad-, trasladados a un escenario y vistos ahora desde la barrera, diseccionados ante el patio de butacas, estos personajes no son más que productos atónitos de ALGO —llamémosle historia, cultura, familia, tiempo- que no han podido o no han sabido controlar. ;Y que se les ha ido de las manos!

Nos interesamos particularmente por esta creación pensando en la crítica de Xosé Lueiro evocando un trabajo actoral «tráxico e grotesco a un tempo» (Lueiro, 2008: s/p). Vamos a interrogar, por lo tanto, la dimensión grotesca de este montaje, tanto desde el punto de vista del trabajo actoral como de la escenografía o del dispositivo escénico.

\subsubsection{El trágico espacio-tiempo de lo grotesco}

Si nos basamos en los orígenes de lo grotesco, la dimensión espacial es fundamental. Es también una dimensión esencial de la creación teatral, en la 
que se relaciona estrechamente con el tiempo. El espacio-tiempo cobra tanto más importancia en el teatro de Ana Vallés cuanto que suele cuestionar los límites de la representación teatral. La «sinopsis» que citamos lo evidencia: reivindica la ausencia de decorado y afirma su presencia escénica como un «yo», o sea como persona y no como personaje, poniendo en tela de juicio la ilusión teatral.

El espacio escénico no deja de ser ambivalente: si bien el espectador sabe que es un escenario, el espectáculo empieza (después de casi cuatro minutos en los que los actores parecen instalarse, prepararse) con un discurso de Ana rompiendo la cuarta pared y dirigiéndose directamente al público: «Buenos días. Señoras y señores, todos los que estamos aquí hoy hemos pasado hace tiempo de los cuarenta». Así que el espacio escénico pierde su delimitación tradicional y se borran las fronteras. Si no es un escenario, tal vez sea un aula, una sala de estudio, por la mesa que ocupa el centro del escenario, por la pizarra al fondo... O el laboratorio de anatomía, por el cuerpo desnudo y el esqueleto que manipulan tres actores. La incertidumbre viene reforzada por las luces, centradas principalmente en la mesa, dejando el resto del escenario en una penumbra más o menos marcada, mientras el suelo, gris y brillante, refleja la mesa, los actores cual una superficie líquida.

Esta penumbra, la ausencia de decorado, el color negro o gris oscuro omnipresente, pueden evocar a la vez un «no lugar», desconectado de cualquier lugar existente o una gruta en las paredes, en la cual se dibujan las sombras, con un parecido con la caverna de Platón que puede despertar la vigilancia del receptor, invitándole a superar las apariencias, a buscar más allá de lo que ve, a interrogar el ser y el estar de estos seres que van actuando, bailando, hablando ante sus ojos.

Estos juegos de luz y sombra, además de los efectos estéticos que generan, confieren más espacio y más relevancia a los cuerpos que ocupan el escenario, a la vez que multiplican sus posibilidades tanto a nivel del juego actoral como de la interpretación por parte del espectador. Y de hecho, el espacio escénico viene configurado por el discurso, los cuerpos de los actores, por su presencia escénica:

Formalmente, no que atingue á configuración do espazo escénico, e conceptualmente, na emulsión dun discurso fragmentario, na elección de linguaxes, no tratamento do traballo actoral —-tráxico e grotesco a un tempoe na relación que establece co contexto do espectador (Lueiro, 2008: s/p). 
Del mismo modo que el montaje subvierte las fronteras y elimina el decorado creando un espacio minimalista y abierto, sugerente y creativo, juega con la noción de tiempo. O, mejor dicho, parece transgredir el tiempo dramático, exhibiendo exclusivamente al tiempo de los actores: se maquillan y visten a la vista del público; comparten con el auditorio sus dudas y experiencias. Es así como presenciamos una serie de entrevistas que participan de la creación dramática, pero que se refieren a los actores/bailarines -Perico Bermúdez, Mauricio González...- bajo su nombre verdadero. Incluso llegan a ser evocados datos biográficos auténticos.

Estas transgresiones, por la negación de lo normativo, de lo reglamentado, proporcionan un espacio-tiempo que facilita la emergencia de lo grotesco. De hecho, «les règles et les formes héritées [...], le grotesque les transgresse et les défigure, reniant le préconstruit et le déjà institué» (Ost, 2004: 40). Otra característica fundamental es la relación que se crea aquí entre espacio-tiempo y corporeidad.

\subsubsection{El cuerpo grotesco}

La importancia del cuerpo en el trabajo de Matarile Teatro es esencial por la mezcla de teatro y danza, por la importancia de lo visual, por la voluntad de Ana Vallés de crear una poética del cuerpo. La presencia física de los actores es, de hecho, fundamental, y Ana Vallés juega con todas las posibilidades que le ofrece: cuerpos desnudos o disfrazados, cuerpos manipulados o contrahechos, cuerpos congelados (para emplear un término cinematográfico) o bailando... Y es interesante notar, desde la perspectiva que nos interesa, que, entre estas modalidades de la corporeidad, encontramos muchos procedimientos grotescos: las máscaras, la deformación, la ambivalencia y la tensión vida/muerte, la desacralización del Tánatos, la presencia (aunque más tenue que en otras creaciones de Matarile) de Eros.

Ya desde el principio de la obra aparece un cuerpo desnudo: Mauricio González entra cantando, se desviste y, desnudo, escribe en la pizarra antes de extender la sábana y recostarse en ella. La desnudez no es una provocación o una provocación gratuita. Viene a alimentar la comparación entre el cuerpo tendido en la mesa como un muñeco o un cadáver y el esqueleto que los otros personajes están montando. Esta aproximación, además de jugar con los límites entre vida y muerte, confundiéndolos, remite a la desagregación de la carne, crea una imagen fuerte de manipulación del cuerpo, creando una imagen potenciadora de lo grotesco: 
[Les images grotesques conservent] leur contenu, leur matière traditionnels : accouplement, grossesse, accouchement, croissance du corps, vieillesse, désagrégation et dépeçage du corps, etc., dans toute leur matérialité immédiate, demeurent les éléments fondamentaux du système des images grotesques. (Bakhtine, 1998: 34).

Las imágenes de desagregación, deformación, descuartizamiento las volvemos a encontrar más tarde en la obra cuando Mauricio González, después de cubrirse el rostro con una media, corta parte de ésta con una gran tijera, dejando un hueco desproporcionado para la boca, que rellena con una forma blanca, de apariencia blanda, con la cual va a jugar casi dos minutos, dando la impresión, desde la sala, de que está haciendo muecas, distorsionando la boca.

La carnavalización de la escena, que es otra forma de distorsión de la realidad y de la corporeidad, tiene lugar en particular a propósito de los disfraces y el maquillaje. Concretamente, mientras Pedro Bermúdez lee la exposición científica relativa a la evolución de la humanidad, está siendo disfrazado por sus compañeros con hojas de verduras (al parecer, acelgas, calabazas, etc.), quitándole así toda seriedad a la ponencia y confiriéndole una dimensión profundamente grotesca:

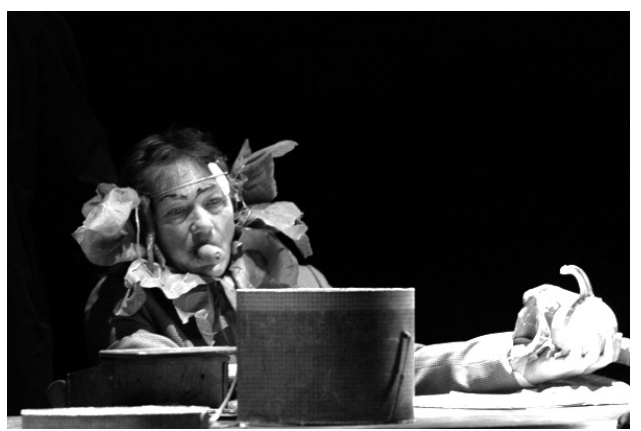

Truenos y misterios. Sala Cuarta Pared de Madrid (01.02.2007).

Creación y dirección: Ana Vallés. Espacio escénico, iluminación,

producción musical y diseño gráfico: Baltasar Patiño. Fotógrafo: Daniel Alonso

Cabe señalar también el uso recurrente de pelucas: por ejemplo, Ana Vallés, conforme va entrevistando a los distintos interlocutores, cambia de pelucas (morena, rubia, de pelo blanco...), se aplica un maquillaje exagera- 
do y voluntariamente imperfecto (excesos de polvos, labios mal y excesivamente pintados...), usa gafas, deforma su dicción con prótesis... Procedimientos que casi todos los actores usan en un momento u otro. Esta carnavalización se extiende incluso al esqueleto que forma parte de auténticos cuadros vivos, vestido como si estuviera vivo él también:

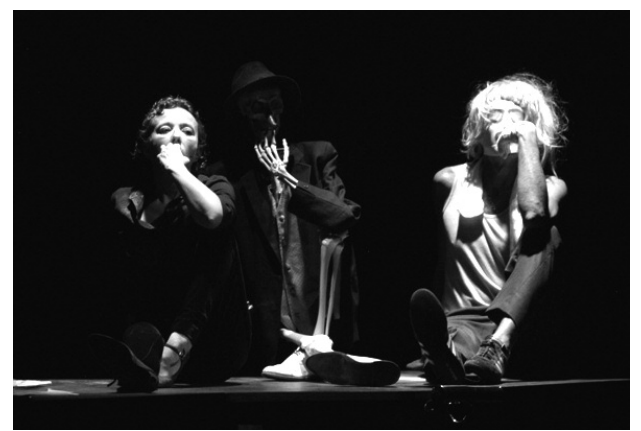

Truenos y misterios. Sala Cuarta Pared de Madrid (01.02.2007).

Creación y dirección: Ana Vallés. Espacio escénico, iluminación, producción musical y diseño gráfico: Baltasar Patiño. Fotógrafo: Daniel Alonso

El uso del esqueleto, además de desdibujar las fronteras vida/muerte y jugar con la ambivalencia, remite a bromas de estudiantes y permite darle a un objeto un destino distinto, renovando su significado: «On donne à l'objet un visage, un emploi, ou une destination qui ne sont pas les siens, voire même diamétralement opposés [...] et l'objet se trouveré nové dans son mode d'existence inédit» (Bakhtine, 1998: 372).

Otro tipo de manipulación que se impone en la obra es la manipulación de los cuerpos vivos como si fueran objetos, en concreto títeres: es así como Ana Vallés hace de marionetista, guiando el baile de Mauricio González, después del «autorretrato con piscina». Otro ejemplo significativo es el de la manipulación del cuerpo de la misma Ana Vallés, cogida a traición por Carlos Sarrió y Mauricio González, vestida por ellos y manipulada como si fuera una marioneta, antes de hacer de enana.

Desempeñando este papel parece jugar a un juego infantil, a la vez que pierde el control de sus movimientos, como un títere, y presenta un cuerpo que simula estar contrahecho. Un cuerpo grotesco, al fin y al cabo. 


\subsection{3. ¿Actores, espectadores? ¿Quién es quién?}

Ya hemos señalado la ruptura de la cuarta pared que abre la comunicación teatral en Truenos y misterios. Esta ruptura marca la violación de la frontera tradicional, transgrediendo el orden preestablecido, jugando con las convenciones. Esta subversión pasa también por la fragmentación del discurso, en el que las rupturas y los desgarros en el texto pronunciado los ocupan en la mayoría de los casos formas de expresión escénica no verbales, como el baile. Otra forma fundamental aquí de discontinuidad en los monólogos y diálogos ya no es tanto la fragmentación, sino más bien la subversión de los códigos elementales de la interlocución, subversión que permite a la vez hacer visibles los mecanismos de la comunicación y crear movimiento, generar energía escénica, nutrir este hilo que va del escenario a la sala, generando teatralidad: los personajes a ratos no se escuchan, no respetan los turnos de palabra, no interactúan.

La actuación pasa de la declamación a la música, del monólogo a los títeres, del diálogo a la danza. Pero es de notar que supera el juego posmoderno de la reutilización de cualquier material imaginable o del «collage»: la danza y las otras formas de expresión corporal son teatro, no son un material, sino que participan de la esencia misma de la expresión teatral, dando la palabra a estos cuerpos grotescos, devolviéndoles su autonomía. Se crea así una tensión entre discontinuidad discursiva y continuidad de la presencia física de los actores, entre fragmentación aparente y coherencia de las imágenes creadas. La tensión alcanza su punto culminante cuando se esboza otro dispositivo que convierte al espectador en un ente esquizofrénico, interlocutor y voyeur a la vez, cuando la actriz/directora, principalmente, se dirige directamente y frontalmente al público, con un discurso que además pone en tela de juicio la relación teatral, no sin una fuerte dosis de ironía y cinismo:

Ana Vallés: [...] Yo misma, que llevo aquí desde hace más de 20 años, tengo dudas para reafirmarme como actriz, y mucho menos como directora. Yo dudo de todo. Temo constantemente no ser lo que la gente espera de mí. No sé explicar cómo se hace mi trabajo. A menudo me preguntan sobre el proceso y doy información; eso es todo. Pero no sé lo que es, de dónde procede. A estas alturas me cuesta hacer cualquier afirmación. Creo que me confundís con otra. Todo es inventado.

Pedro: ¿Todo?

Ana: Todo. 
Esta forma de poner en tela de juicio determinadas ideas preconcebidas, además de romper fronteras y cuestionar códigos, crea complicidad con el receptor y genera humorismo, con lo cual lo grotesco sirve para la renovación del mensaje teatral, a nivel de la forma y del fondo.

Designando a los personajes por los nombres verdaderos de los actores y creando una confusión entre personaje y persona; recurriendo a discursos en primera persona, a veces coincidiendo con la propia vida; rechazando la utilización de un decorado que dé verosimilitud a la acción dramática y negándose a seguir un argumento, Ana Vallés logra pues suscitar una reflexión que cuestiona tanto el papel del personaje como el del espectador. Inicia así un sentimiento de intercambio de papeles, reforzado por la omnipresencia de los actores en un escenario instalado al mismo nivel que los espectadores, omnipresentes también. O sea que, «al fin, los propios espectadores en el teatro deben representar el papel de "espectadores en el teatro" [...] con miras a profundizar el fondo en una forma tal que podría privarse al espectador de su orientación segura del mundo» (Kayser, 1964: 165).

Se inicia así una reflexión sobre la renovación del género teatral a la vez que sobre el significado de la vida y las relaciones humanas. Y lo grotesco invita al espectador a que se descentre, se desubique para verlo todo desde una perspectiva diferente, renovada y portadora de un nuevo prisma para abordar la realidad.

\section{2. ¿Un mundo de animales artificiales?}

Siendo el universo de Ana Vallés una propuesta creativa coherente, encontraremos en Animales artificiales (2008) procedimientos que ya analizamos en Truenos y misterios, en los que no nos detendremos tanto para no repetirnos. Pero, eso sí, en general, los mencionaremos.

\subsubsection{Animalización y carnavalización: ¿desubicar lo humano?}

La primera característica que parece recalcar el título de la obra es la animalización, procedimiento frecuente en la estética grotesca. Esta presentación de una humanidad animalizada se acompaña de una paradoja: la ausencia de naturalidad, siendo ésta habitualmente una propiedad esencial de la animalidad. Y tanto la dimensión animal como la artificialidad vienen sugeridas visualmente mediante el uso de la máscara o más exacta y preci- 
samente de una nariz falsa que no deja de recordar un hocico o una cara de cerdo (ya hemos mencionado el significado y valor de la nariz en lo grotesco).

Este parecido con partes del cuerpo animal provoca una sensación de dualidad, de hibridación, fenómeno del que Christophe Meurée afirma: «L'hybridation, résultat d'une fusion entre un corps humain et un corps animal, est probablement l'une des premières spécificités du grotesque» (Meurée, 2004: 200). Esta hibridación permite otra vez poner en tela de juicio los límites, las fronteras, los prejuicios, o sea lo preestablecido. Esta animalización pasa por la máscara, que se emplea también como disfraz, como pantalla detrás de la cual esconderse o con la cual presentar otra cara de la realidad, otra visión del mundo, «carnavalizada» y grotesca. Subversiva y transgresora.

La animalidad de los personajes, ya evidente por el título y por las máscaras, se traduce también por el vestuario, a medio camino entre el artista de cabaret y un pavo real.

Pero, más inquietante y grotesco a la vez que esta animalización es la animalización de los cuerpos, de los movimientos o los desplazamientos. Así sucede en secuencias tituladas por Ana Vallés «El gigante y el enano», en la que Ricardo Santana se desplaza en cuclillas e incluso a gatas evocando a un animal — tal vez un mono - o alude al enanismo, siendo éste otra desviación de la norma que, aquí, podría inscribirse en lo grotesco.

Las distorsiones y subversiones de la realidad del cuerpo actoral pasan por la máscara, el atrezzo o la deformación voluntaria que se prolonga con recursos ya empleados en Truenos y misterios, como la multiplicación de las pelucas y postizos. Pero, si encontramos usos comparables, cabe notar también la utilización del travestismo, muy presente en este montaje. Es un elemento paródico, con una alta carga grotesca, pero también una manera de borrar o por lo menos cuestionar un límite, una frontera más. Tanto más cuanto que las pelucas no pretenden confundirse con una cabellera auténtica, ni el travestido con el sexo opuesto, siendo el parecido imperfecto: suelen aparecer rasgos característicos del verdadero sexo del personaje, como, por ejemplo, una espalda peluda y masculina evidenciada por un vestido rojo con la cremallera abierta. Y esta identidad sexual se revela con el último recurso que queríamos evocar: los cuerpos a medio vestir, en general desnudos en la parte inferior y con camisa, chaqueta o ropa de ciudad en la parte superior. Este aspecto entre desaliñado y ridículo participa de la dimensión grotesca, pero es también un eco visual al título: una mezcla entre animalidad y arti- 
ficialidad, entre naturalidad y civilización, planteando la pregunta fundamental de dónde empieza uno y dónde acaba el otro.

\subsubsection{Pintar nuevos arabescos en el espacio escénico}

Podemos volver a plantear, pensando en estos cuerpos, una pregunta que ya hicimos al estudiar la obra de Albert Boadella, Yo tengo un tío en América: «Ces corps grotesques n'acquièrent-ils pas, en même temps qu'ils perdent en humanité, une plus grande liberté, représentant autre chose qu'eux-mêmes, dessinant de nouvelles arabesques dans l'espace scénique?» (Surbezy, 2002: 67). Una pregunta que parece ineludible si pensamos en el altísimo nivel significativo de la corporeidad y la expresión física, el baile y lo visual, en el teatro de Ana Vallés. Y, de hecho, está omnipresente la danza, una danza claramente inspirada en Pina Bausch, con cuerpos a veces mecanizados, a veces dolorosos, y en otros momentos exultantes, radiantes, sensuales. Con la gran variedad de registros propuestos, con la riqueza de la expresión corporal, parece que la directora quiere pintar nuevos arabescos en el espacio escénico, en busca de un nuevo lenguaje escénico y de una renovación del mensaje teatral.

Entre las figuras que dibujan los cuerpos en movimiento, unas llamaron particularmente nuestra atención: en primer lugar, los cuerpo a cuerpo que parecen simular una pelea o un acto sexual, orientando las imágenes creadas hacia lo bajo corporal y hacia lo grotesco: «l'orientation vers le bas est propre aux bagarres, mêlées et coups: ceux-ci renversent, jettent à terre, foulent aux pieds. Ils ensevelissent» (Bakhtine, 1998: 368). Otra que nos parece particularmente interesante es la mecanización, la «robotización» de los cuerpos. De hecho, el espectador presencia fenómenos de «marionetización», bastante equiparables a los que hemos analizado ya, pero también danzas con una gestualidad discontinua, entrecortada, rígida, que evoca a un autómata antes que a un ser humano. Es el caso del baile, por ejemplo, de Helen Bertels.

Hecho notable, en este caso, se asocian dos procedimientos ya mencionados: la automatización del movimiento y la «marionetizacion», puesto que después del baile solitario, el cuerpo de la actriz será manipulado por Ricardo Santana como si fuera un títere, antes de lanzarlo a bailar un tango dirigido todavía por el actor.

Ya que hemos hablado antes de hibridación y hemos evocado la mezcla de formas tradicionalmente distintas, nos gustaría señalar que no se trata sólo 
de un dialogismo que se traduzca por una alternancia dialéctica de las formas sino que entran en concomitancia y en diálogo en varias secuencias, cuando se asocian un discurso verbal (monólogo o diálogo) con la danza o cuando, como en la escena del can-can de los hombres, se entretejen las influencias y las fuentes de inspiración. En este caso, si la presencia del cabaret es innegable, adquiere una dimensión particular por la música, circense; por el baile de las mujeres, que puede recordar el kazatchok $k^{4}$ y por unos contoneos exagerados que refuerzan la dimensión grotesca de esta secuencia de baile tan híbrida como humorística, en una obra que juega permanentemente con los límites y los códigos, otorgando a la creación de imágenes escénica un espacio particularmente significativo.

Elegimos no detenernos en el lenguaje verbal, por muy interesante que sea, porque nos llevaría a repetir, aunque con ejemplos distintos, muchas consideraciones que ya barajamos: la ambivalencia persona/personaje, la ruptura de los límites escenario/sala, la fragmentación y la discontinuidad, los fallos comunicativos... Nos pareció más relevante en relación con nuestra perspectiva, y más complementario con el acercamiento a Truenos y misterios, centrarnos en la dimensión corporal y visual. La predominancia de este aspecto viene sugerido por este comentario de Gordon Craig: Animales artificiales es «un espectáculo, en fin, hecho de imágenes, que apela - como en ocasiones anteriores - a la fibra sensorial del espectador y a su dimensión imaginativa, y que encierra una nada desdeñable carga de energía liberadora» (Craig, 2008: s/p). Valiéndose de cuerpos y procedimientos grotescos, Ana Vallés intenta pues superar los límites tradicionales, derrumbar las fronteras, las impuestas por la sociedad y las que nos inventamos nosotros mismos. Y con esta lengua teatral renovada, prosigue en su afán de cambiar la perspectiva, de cambiar el esquema de pensamiento de los receptores.

Desde dos perspectivas distintas, el texto por una parte y la expresión corporal por otra; desde dos vertientes distintas de lo grotesco, una más paródica y centrada en proceso de reescritura, otra más inscrita en una dinámica de hibridación y cuestionamiento de las fronteras intergenéricas, Antonia Bueno y Ana Vallés interrogan la teatralidad. Haciéndolo, se valen de lo grotesco para cuestionar el mundo que nos rodea, recordando al receptor la necesidad de cambiar de prisma para acceder, si no a la verdad o la realidad, sí a una renovación del lenguaje teatral y de la recepción, esperando que

${ }^{4}$ El kazatchok es una danza tradicional ucraniana. Se caracteriza por saltos y movimientos en los que los bailarines en cuclillas lanzan las piernas alternativamente. 
esta renovación traiga consigo una renovación de nuestra percepción del mundo.

\section{REFERENCIAS BIBLIOGRÁFICAS}

BAKHTINE, M. (1998). L'Euvre de François Rabelais et la culture populaire au Moyen Âge et sous la Renaissance. Paris: Gallimard.

BUENO, A. (2011). «Breve reflexión sobre mi teatro breve: El otro monólogo imposible». En El teatro breve en los inicios del siglo XXI, José Romera Castillo (ed.). 35-43. Madrid: Visor Libros.

CRAIG, G. (2008). «Animales artificiales. Antinatural por naturaleza». En Soitu.es, 5 de mayo. http://www.matarileteatro.com/archivos/animales/ ingles/critica.html.

GARCÍA PASCUAL, R. (2006). «Lo grotesco en el teatro breve de los autores de tendencia neorrealista y neovanguardista». Cuadernos del Ateneo 21, 23-28.

IEHL, D. (1997). Le grotesque. Paris: PUF.

KAYSER, W. (1964). Lo Grotesco. Su configuración en pintura y literatura. Buenos Aires: Nova.

LUEIRO, X. (2008). «Emocións e memoria». En Elcorreogallego.es, 29 de enero. http://www.elcorreogallego.es/indexSuplementos.php?idMenu $=20 \&$ idNoticia $=179871$ \&idEdicion $=558$.

MEURÉE, C. (2004). «Du singe qui pleure le matin: analyse de la matière grotesque dans Quaiouest et Le retouraudésert de Bernard-Marie Koltès». En Le grotesque. Théorie, généalogie, figures, I. Ost, P. Piret y L. Van Eynde (eds.), 197-216. Bruxelles: Publications des Facultés Universitaires Saint-Louis.

OST, I. (2004). «Le jeu du grotesque ou le miroir brisé». En Le grotesque. Théorie, généalogie, figures, I. Ost, P. Piret y L. Van Eynde (eds.), 29-42. Bruxelles: Publications des Facultés Universitaires Saint-Louis.

- PIRET, P. y VAN EYNDE, L. (2004). Le grotesque. Théorie, généalogie, figures, Bruxelles: Publications des Facultés Universitaires Saint-Louis.

ROSWITA / VASSEROT, Ch. (2002). Le corps grotesque. Carnières: Lansman. 
SURBEZY, A. (2002). «Le corps en folie: aliénation et grotesque chez Albert Boadella (Yo tengo un tío en América)». En Le corps grotesque, Roswita/Ch. Vasserot (eds). 63-72. Carnières: Lansman.

WELLNITZ, P. (1999). Le Théâtre de Friedrich Durrenmatt : de la satire au grotesque. Strasbourg: Presses Universitaires de Strasbourg.

- (2004). «Le grotesque littéraire — simple style ou genre à part entière?». En Le grotesque. Théorie, généalogie, figures, I. Ost, P. Piret y L. Van Eynde (eds.), 15-27. Bruxelles: Publications des Facultés Universitaires Saint-Louis. 